\title{
IRISH STUDIES IN SPAIN - 2019
}

\author{
María Losada Friend (ed.)
}

Copyright (c) 2020 by the authors. This text may be archived and redistributed both in electronic form and in hard copy, provided that the author and journal are properly cited and no fee is charged for access.

\section{Introduction}

María Losada Friend .223

Orality in Written Texts. Using Historical Corpora to Investigate Irish English 1700-1900. Carolina P. Amador Moreno

María José Carrillo Linares. .227

Joyce's Heirs: Joyce's Imprint on Recent Global Literatures

Olga Fernández Vicente, Mari Mar Boillos Pereira, Richard Jorge Fernández and Paulo Cortázar Billelabeitia, eds.

Margarita Estévez-Saá..............................................................230

Samuel Beckett en español. Bibliografía crítica de las traducciones de su obra.

Nuria Fernández-Quesada, José Francisco Fernández, Bernardo Santano Moreno.

María José Carrera.

Hannah Lynch and Spain: Collected Journalism of an Irish New Woman, 1892-1903.

Pere Gifra-Adroher and Jacqueline Hurtley

Verónica Membrive Pérez

¡Salud! Un irlandés en la Guerra Civil española. Peadar O’Donnell.

Alberto Lázaro, ed.

Marisol Morales-Ladrón .238 


\section{Introduction}

\section{María Losada Friend}

The year 2019 was the Year of the Harp in Ireland. We witnessed a myriad of celebrations around the annual National Harp Day in October and UNESCO inscribed this emblematic instrument in the Representative List of Intangible Cultural Heritage of Humanity. The recognition of the harp as a symbol of Ireland's living heritage filled the island with seminars, demonstrations of harp-making and concerts, and the echoes of those soothing melodies still resound in our ears.

Together with the harp's gentle strains, other different tunes have reached us bringing the sounds of economic, political and cultural changes that prove Ireland's unstoppable march in this decade. Optimistic data show the country's development as one of the youngest nations in Europe and its thriving economic results confirm that the Celtic Tiger has apparently surmounted previous dramatic crises. Forbes 2019 list ranks Ireland in the $11^{\text {th }}$ position of Best Countries for Business which qualifies the country as a favoured location for investment in Europe. Post-Brexit era arrives blended with new expectations after an election that has shown the end of the two party system of Fianna Fáil and Fine Gael and the emergence of the Sinn Féin with the largest vote. Irish ecological awareness has been proved as many demonstrations took place in the country running parallel to Limerick's award and title of European Green Leaf 2020 for smaller cities. Also, a new treasure from the Irish cultural past has been recovered with the discovery of a Jack Butler Yeats' painting ("A White Jug") hidden in a bank vault. Finally, Edna O'Brien's success in winning the biennial David Cohen Award proves Ireland's continuity of literary natural talents. Previous awarded authors of this "UK and Ireland Nobel award" are V.S. Naipul (1993), Harold Pinter (1995), William Trevor (1999), Julian Barnes (2011), Derek Mahon (2007), Seamus Heaney (2009) and Tom Stoppard (2017).

The vibrant echoes of these news from the Emerald isle play in harmony with the many cultural and academic events that prove Spain's active and energetic commitment to Irish issues and studies. A general overview on this year's productions verifies that 2019 has been prolific. Musical and poetic celebrations, conferences, articles, books and reviews give evidence of the successful combined efforts of Spanish and Irish universities, EFACIS Centres for Irish Studies in Spain, the Irish Itinerary EFACIS, the Irish Embassy in Spain and other institutions in the Spanish territory which, together with the radio program Live on Eire, connect our cultures and languages.

March officially opened the academic season with the publication of volume 14 of Estudios Irlandeses/Journal of Irish Studies of the Spanish Association of Irish Studies (AEDEI) keeping to its traditional launching on St. Patrick's Day. Together with the 2019 special issue 14.2 ("Samuel Beckett and Biopolitics" edited by Seán Kennedy) both volumes confirm the international academic repute of the journal which has recently been upgraded in the ranking of the scientific journals in Spain (FECyT/Fundación Española para la Ciencia y Tecnología), being now number 14 out of the 52 Spanish qualified journals (Linguistics Section).

Some other events took place in Spain around St. Patrick's Day. The Centre for Irish Studies Banna/Bond-EFACIS (Burgos, Deusto, La Rioja and Zaragoza) directed by Melania Terrazas Gallego organized the II St. Patrick's International Seminar: Women in Irish Culture at the University of La Rioja, with guest writer Alan McMonagle among other many speakers, an exhibition on the Irish in Latin America, a poster competition, and an Irish music concert. Also at the University of Almeria, Elena Jaime Palacios coordinated the III International Seminar on Irish Studies with Belinda Caroll's talk ("Green Cultural- A 
Glimpse of Ireland in the $21^{\text {st }}$ century") and the participation of other AEDEI members. Simultaneously, in Malaga, St. Patrick's Day provided the frame for the celebration of an interesting homage to Robert Boyd and St. Patrick's Battalion at the Centro de Interpretación José María Torrijos. It included the presentation of the Robert Boyd Award promoted by the AMZET (Aula María Zambrano of Transatlantic Studies at the University of Malaga). This award encourages research on works related to historical relations between Spain and Ireland and adds to the already existent George Campell Award (artistic and musical relations) and Kate O'Brien Award (literary and gender relations).

May opened up with the $5^{\text {th }}$ International Conference of the Samuel Beckett Society at the University of Almeria organized by AEDEI member José Francisco Fernández. The previous edition of this event had taken place in Mexico DF and bringing it to Spain was a successful achievement. Its programme (Beckett and Translation) gave visibility to the many scholars and experts interested in the reading of Beckett's works in different languages. Plenary speakers were Erika Tophoven, Beckett's translator into German, and Marek Kedzierski, Polish writer, critic, translator and theatre director. As a complement to the academic programme, the Mouth on Fire Theatre Company performed Rockay and Not I by Beckett at the Teatro Apolo.

On 23-24 May an international conference on the contemporary short story took place at the University of Santiago de Compostela. Organized by Manuela Palacios González and entitled Borders, Intersections and Identity in the Contemporary Short Story in English, it counted on the participation of important academic Irish voices as Anne Fogarty (University College Dublin) with "Skins almost touched: Borders and the Posthuman in Contemporary Short Stories by Irish Women Writers" and writer Mary O'Donnell "Breaching the intimate and Geographical in the Empires of Heart and Nation". Also in May (25-26), on the occasion of the 30th Anniversary of the Spanish James Joyce Association, with the collaboration of the Department of English and American Literatures at University of Seville, Ricardo Navarrete organized a commemorative international conference (El legado de Joyce treinta años después/Joyce's Legacy Thirty Years Later) to celebrate the re-encounter of the founding members of the Association and to expose new critical voices on Joyce's works and influence.

May rounded up with the successful $18^{\text {th }}$ International Conference of the Spanish Association of Irish Studies which took place in northern Majorca, between Alcudia and Pollença. Organized by Aida Rosende Pérez and Rubén Jarazo at the University of the Balearic Islands its thought provoking title (Difference and Indifference in Irish Studies) encompassed an excellent repertoire of academic keynote speakers and writers. Anne Mulhall (University College Dublin), co-director of the UCD Center for Gender, Feminisms and Sexualities, participated with her talk "Decentering Whiteness in Irish Literary 'Multiculturalism"' as did activist Ailbhe Smyth, former head of Women's Studies (WERRC) at University College Dublin representing a strong voice in the Coalition to Repeal the Eight Amendment. There was also a reading by Melatu-Uche Okorie, Nigerian writer and asylum seeker in Ireland, awarded the 2009 Metro Éireann Writing for her short story "Gathering Thoughts". Contributor for different journals, her late work has been the collection This Hostel Life (2018). Besides, writer Lisa McInerney, renowned and awarded for The Glorious Heresies and The Blood Miracles, gave a preview of her third novel, the sequel that completes her three-volume oeuvre written in "a kind of Barrytown Trilogy way", as she explains making reference to Roddy Doyle's trilogy.

Summer brought many events which took place all around Spain. In June, Irish poet John Liddy attended the Book Fair in Madrid and the Nuala Irish Dancers's performance in Barcelona embellished their $10^{\text {th }}$ anniversary with music and dance. Bloomsday did not go unnoticed: celebrations took place in Barcelona at the Ateneu, a James Joyce Fiesta was organized in Bilbao by the Vasque-Irish Association LagunaCara, and Zaragoza came up with 
different acts under the suggestive title of "Visions of love in music and words from Joyce's Ulysses". Madrid was the place for the Yeats Society to host an evening of poetry and music and for the Bloomsday Society to arrange an homage to the Irish author and hispanist Ian Gibson.

On that same note, it was a pleasure for all AEDEI members to support the nomination of Ian Gibson for the Presidential Distinguished Service Awards for the Irish Abroad for 2019. Gibson received the distinction in Dublin in November and he sent a warm letter of gratitude to AEDEI President Asier Altuna assertively declaring that Ireland and Spain are not only united by a firm friendship but also by millenary bindings.

The well-known international summer Festival of Classical Theatre in Almagro included this year an Irish touch as on 23-24 July Irish actor and director Denis Rafter represented the monologue "Don Quijote de Dublín".

In September, the seminar A View of the Irish Language organized by David Clark and the Amergin Institute of Irish Studies in A Coruña, had among other speakers Ciarán Dawson (University College Cork) who talked about new trends in sociolinguistic studies in Ireland and Galicia. In the same month, another international seminar in the north of Spain entitled The Animal Trope: On Literary and Empirical Animals was organized by Manuela Palacios González at the University of Santiago de Compostela in collaboration with the University of Vigo. It benefited from the participation of Irish writer Anne Haverty (Irish Itinerary EFACIS) and Maureen O'Connor (University College Cork).

On 24-25 October the Tenth International George Moore Conference took place at the University of Almeria. Organized by Elena Jaime de Pablos and entitled Truth, Innovation and Commitment: The Artistic Legacy of George Moore, it hosted relevant speakers as Adrian Frazier (National University of Ireland) with "Elizabeth Jane Gardner, George Moore, and the Question of the Woman Artist" and Elizabeth Grubgeld (Oklahoma State University, USA) with "Framing the Folk: Modernist Metropolitanism and the Regional Subject". Besides, Conor Montague (National University of Ireland) performed the monologue "Confessions of a Middle-Aged Man: "The difficulty in life is the choice".

Simultaneously in October, a joyful weekend of music and culture gathered national and international artists at the $16^{\text {th }}$ edition of the Caceres Festival Irish Fledabh. With the help of AEDEI member Carolina Amador (University of Extremadura) and the organizing committee, this annual and prestigious event offered parallel activities such as workshops, film projections, book presentations and a lecture by Auxiliadora Pérez Vides on the Magdalene laundries entitled "Los silencios revelados de las lavanderías de la Magdalena en Irlanda".

There was also a profusion of other festivals related to Ireland along the year. Still in October, the Irish Festival Sitges Live '19 provided its so-called Fringe and Garden events; in June, the $2^{\text {nd }}$ edition of "CeltaSur" brought music and dance in the Cúllar Vega in Granada, as did in July the $9^{\text {th }}$ Catalunya Celta Festival. Other musical events in November offered interesting programmes such as "Schönberg and Music in Ireland in the XXI century" held at the Auditorio Nacional in Madrid in collaboration with the contemporary Music Centre in Dublin by the Fabián Panisello Plural Ensemble with works by Jane O'Leary, Dierdre Gribbin, Garth Knos, Kevin O'Connell and Ed Bennett.

On 8 November, the Efacis Center for Irish Studies at the University of Granada (with the Universities of Almeria and Jaen) sponsored by the Irish Embassy in Spain, the MA program of language and literature in English language and the Department of English and German Philologies organized the Spanish-Irish musical/poetry concert to celebrate the $120^{\text {th }}$ anniversary of Federico García Lorca's birth. Directed by AEDEI member Pilar Villar-Argáiz and entitled Locos por Lorca: An Irish Celebration of the Great Spanish Poet it had as special guests Irish poets Theo Dorgan and Keith Payne, Irish musician Cormac Juan Breatnach, and 
AEDEI scholar and writer Gerardo Rodríguez-Salas. García Lorca's poems translated into English and Irish were read accompanied by music and images.

In that same month, on 13-15 November there was a joint activity at the Centre of Irish Studies Banna/Bond in collaboration with EFACIS at the Universities of Burgos and La Rioja. The international seminar entitled Humanity and Inhumanity in Contemporary Irish Culture unveiled how Irish authors from the Republic of Ireland and Northern Ireland creatively represent issues related to social activism and social responsibility in a dehumanized society.

Moreover, different exhibitions all over Spain brought Ireland to us. Scholars, students and the general public were able to contemplate the important folio from the $12^{\text {th }}$ century Book of Leinster, a priceless medieval manuscript from the Irish Language Collection at Dublin's Trinity College at Galicia, un relato no mundo/Galicia, a story in the world in the Museo Centro Gaiás in Santiago de Compostela. It will run until April 2020.

Art from or about Ireland has been exhibited from north to south. O Camiño por Mar de Dublín a Compostela ran from June till October 2019 in the Museo do Mar in Vigo. In June-July 2019 the exhibition of photographs La Irlanda de Plácido Castro was shown at Vilagarcía de Arousa (Pontevedra). Also, the Eamonn Doyle Exhibition was at the Fundación Mapfre in Madrid (September 2019-January 2020) showing the production of the well-known photographer and creator of the original Dublin trilogy $(i, O N$, End $)$ and its sequel $K$ (about West Ireland and Spain). The Centro de Arte Contemporáneo in Malaga reopened to host Sean Scully's exhibition, Eleuthera (October 2019-January 2020).

At the end of the summer, the Annual General Meeting at Ljubljana (31 August 2019) brought the election of the new EFACIS executive and EFACIS board. Katharina Rennhak (University of Wuppertal) was elected president and thanked the outgoing president Seán Crosson. She also welcomed the new EFACIS Board, with Spanish AEDEI member Pilar Villar-Argáiz (University of Granada) as one of its members. The new President promised to make the EFACIS federation relevant for those engaged in Irish Studies across Europe "in a truly European spirit".

Apart from the above mentioned, numerous Spanish works on Irish Studies have been published. Gustavo Adolfo Rodríguez Martín provides an annotated bibliography in the latest issue of the journal Shaw (39.2) with reviews of some works by AEDEI members.

Also more academic achievements can be traced in the IASIL Bibliography kindly compiled by María Jesús Lorenzo Modia which is annually published in the Irish University Review. Christopher Cusack is now chair of its Bibliography committee, substituting former editor Beatriz Kopschitz Bastos in the 2019 publication (49.2). In its foreword Cusack has confirmed the increasing interest in Irish women's writing and the representation of other marginalised voices. He expects more diversification in the area of Irish literary studies "including more work on Irish-language writing, diasporic authors and children's and Young Adult literature" and his goal is to offer a fully hyperlinked bibliography in the future.

Also, works by Spanish scholars on Irish issues are transcending borders. Cooperation with Brasil, for example, has resulted in the volume "Contemplating Feminism(s): Women Writers and Women Critics" co-edited by Mariana Bolfarine and Marisol Morales-Ladrón in ABEI Journal: The Brazilian Journal of Irish Studies (20.2) with the participation of various AEDEI members._Similarly, Pilar Villar-Argáiz, editor of the new major interdisciplinary series Studies in Irish Literature, Cinema and Culture (Edward Everett Root Publishers), announces promising volumes such as: Constanza del Río, ed. Revolutionary Ireland, 19162016. Historical Facts and Social Transformations Reassessed; Katharyn Laing and Sinéad Mooney, eds. Irish Women Writers at the Turn of the Twentieth Century: Alternative Histories, New Narratives; Adela Flamarike's Women, Art and Nationalism in the Irish 
Revival. Presence and Absence, or James Gallacherd's Bohemian Belfast and Dublin: Two Artistic and Literary Worlds in the Work of Gerard Keenan.

Important achievements have to be mentioned in the area of translation. Manuela Palacios' project "Crosswinds: Irish and Galician Poetry and Translation" with the collaboration of AEDEI members shows current results on translations of Irish and Galician poetry. She has also written the introduction to The Mouth of the Earth (Shearsman, 2019), translation into English by the Irish poet Lorna Shaghnessy of the collection A Boca da terra by Galician poet Manuel Rivas. Also, José Francisco Fernández with Un caso entre Mil (2019) has translated Samuel Beckett's work (A Case in a Thousand) in a bilingual edition with a complete critical introduction.

Many other successful publications include the enlightening volume edited by Antonio Raúl de Toro and Eduardo Barros (Looking Out on the Fields. Reimagining Irish Literature and Culture (TIR, 2018) or Raul de Toro's edition, Words and Music in Irish Literature (Francis Boutle Publishers, 2019). Both include the participation of many experts and AEDEI members and honour professor de Toro's academic retirement.

To all this, five reviews by expert scholars to whom I am extremely grateful are added in the following pages. The reviewed volumes prove the high quality of the research done in Spain on different issues related to Irish studies. They cover the study of oral language in written texts in Irish English, a compilation of articles tracing Joyce's legacy, an extensive critical bibliography on Beckett's translations in Spanish, a critical edition of Hannah Lynch's articles on Spain, and the critical edition of an annotated and commented translation of Peadar O'Donell's travel book in Spain during the Civil War.

María Losada Friend is a senior lecturer in the English Department at the University of Huelva, presently teaching at the University Pablo de Olavide (Seville). A long standing AEDEI member, she was co-organizer of the EFACIS Conference at the University of Seville (2007) and President of the Organizing Committee of the 11th AEDEI Conference at the University of Huelva (2012). Co-editor of Dreaming the Future: New Horizons/Old Barriers in 21st-Century Ireland- (Irish Studies in Europe, vol.3, 2011) and Words of Crisis/Crisis of Words: Ireland and the Representation of Critical Times (2016), she has also published works on Oliver Goldsmith, James Joyce and Edna O’Brien.

mlosfri@upo.es

Orality in Written Texts. Using Historical Corpora to Investigate Irish English 1700-1900.

Carolina P. Amador-Moreno

London: Routledge, 2019. 211 pp.

ISBN: 9781138902346

Reviewer: María José Carrillo Linares (University of Huelva)

Any comprehensive study of a language requires deep insight into its structure and the paths and turns that the language has taken and which have conditioned the output we come across, both in its present state or in any, remains from the past. Far from being monolithic, a language owes its plurality among other factors to social contexts, regional boundaries, time, political constraints, and individual speakers along its history. Thus, the history of a language is the history of its varieties and subvarieties: a massive jigsaw puzzle where most of the 
pieces are missing and the extant ones are not always neat and clear. An attempt to reconstruct the past is essential in order to achieve a better understanding of the present, and the best historical linguists can do is to contribute by bringing out some of these extant pieces and shedding some light on them.

Orality in Written Texts. Using Historical Corpora to Investigate Irish English 17001900 is such a scholarly contribution, through which the oral language, one of the biggest gaps in the historical puzzle, can be dimly lit. This study is a snap shot that contributes to make up the incomplete picture. The general approach of the book shares some of the principles of micro-history, making everyday common events, such as private letters, the object of study. In doing so, the author, like micro-historians, holds a microscope rather than a telescope in her hands, bringing together elements of social, cultural and language history. Again, as in micro-history, the ultimate aim is to look for the answers to greater historical questions. In this work the author's contributes with some new pieces to the English language puzzle.

Corpus Linguistics is the methodological framework for the analysis, and it is mainly carried out using "A Corpus of Irish English Correspondence" (CORIECOR), currently being compiled by Carolina Amador-Moreno and Kevin McCafferty. The corpus consists of emigrant letters, mostly of a Northern Irish origin, from c. 1800 to 1900 . The data extracted from this corpus are compared to those extracted from other corpora such as "The Corpus of Late Modern English Texts" (for British English) or the "Corpus of Modern Scottish Writing" (for Scottish English) among others. The focus of the study resides in structures that portray an oral component in the linguistic output of Irish emigrants in Canada, USA, Australia, New Zealand, Argentina and UK, and some of their relatives and friends in Ireland.

The book is divided into seven sections, three of which treat the theoretical approach to the subject, three more, the corpus analysis, and the last one is a three-page section of concluding remarks. The introductory chapter sets the context for the analysis that will be carried out in the second part of the book. Here, the general aim of this study is established: to explore how written correspondence can provide evidence of how oral Irish English was used in the past and how speech-like features can be recorded in these writings. The analysis carried out is justified by an extensive and thorough theoretical background. The main focus falls on historical sociolinguistics, historical pragmatics, letter writing, and their application and processing through corpus linguistics.

The second chapter deals with other areas which are essential to carry out any sociolinguistic analysis: the historical context in which the letters were written is scrutinised and issues about Irish migration and its relation to education and literacy are discussed. Likewise, as another element of the matrix, the author addresses in this block the linguistic situation of Ireland and the relation of Irish English with Irish, its Celtic neighbour.

Chapter three focuses on assessing the role of letters for research into the history of a language as a complement of other more traditional research sources. The letters studied allow access to the private lives of ordinary people. They combine formulaic language with different degrees of formality or even informal language, thus portraying a wide scope of registers and in this case the social life of Irish letter writers. The author rightly claims that even if letters are not speech they provide useful information about communicative habits or changes in styles.

The next block of chapters moves onto the analysis of certain "oral" linguistic features in the corpora. Chapter four tackles specific issues such as "Discourse-pragmatic markers". Examples retrieved from the corpus are discussed. The markers analysed are "so", "anyhow", "anyway", "like", "sure". The corpus analysis seems to contradict some previous ideas about the dialectal character of some markers such as "anyways", and it also corroborates previous thoughts on the use of "like". Of special interest is the description of the use of "sure", since 
many of the elements taken into account for the analysis as a whole are not dialectal in nature, most of them occurring in different varieties. The particular present-day Irish English use of "sure" as a discourse-pragmatic marker is exemplified with historical instances as early as the 1760 s and the author considers this dialectal feature in the letters an indicator of identity marking.

Chapter five is devoted to "deictics" which are seen as markers of "the sense of immediacy that is characteristic of spoken discourse" and thus, included in the analysis as examples of oral features in written texts. Spatial deixis is exemplified with "here" and "there" or "this" and "that"; personal deictics with examples of the use of personal pronouns. From the dialectal point of view the most significant pronominal forms in the chapter are those for the second person singular and plural, as the rest of them do not show any sort of variation across time or space. No time deictics are mentioned. The conclusions in this chapter go beyond the linguistic interpretation to enter the field of psychology through emotions and feelings that the author attributes to the use of these linguistic elements.

The last chapter in the analysis deals with "embedded questions". Here again, orality is understood in the act of asking questions, and the focus is on the particular interrogative type where there is an inversion of subject-verb that some varieties of English do not allow for in formal discourse. Some authors have connected this pattern with the interference of Irish in bilingual speakers and the subsequent spread of the inverted structure to monolingual speakers of Irish English. However, the pattern is widespread in overseas varieties of English, such as American English, Australian English or different varieties in Asia. The analysis of the data in CORIECOR does not reach a definite conclusion regarding this matter, and the author suggests that both language contact and the fact that it was a pragmatically useful construction were equally responsible for the emergence and survival of such a structure.

All in all, Orality in Written Texts. Using Historical Corpora to Investigate Irish English 1700-1900 is a valuable study. From the viewpoint of historical dialectologists, the strongest points in the book have to do with the possibilities mentioned several times throughout the work for comparing the results of this analysis with similar ones on certain features in varieties of English which, in some way, have been in contact with Irish English. From a more historical linguists' point of view, a much better understanding of overseas varieties and their history can be achieved through the comparison of what seems to have been dialectal features in the varieties of English spoken by the immigrants that settled in different regions or countries. Thus, studies of this type are welcome. The weakest point from a linguistic perspective, however, seems to be the chapter on 'deictics' since these are not strictly strong markers of orality. Besides, the linguistic analysis here cannot serve to draw conclusions about the history of this particular variety, nor are the psychological conclusions drawn from the usage of these features always totally convincing, as they are generalisations difficult to prove. The bibliography revised for the all the chapters is comprehensive, covering all these areas dealt with in the work. As a whole, this book is an interesting and valuable contribution to the fields of Irish Studies and the History of English even if the discussion of more oral dialectal forms would have been highly desirable to provide a wider scope and more elements to compare with other varieties of English with a view towards filling further gaps in the English language historical puzzle.

María José Carrillo-Linares is Senior Lecturer at the University of Huelva (Spain). She graduated from the University of Seville in 1991 where she also got her doctorate in 1997. Since 1995 she has been teaching and researching at the University of Huelva. Her main research interests have been Middle English scientific manuscripts and English historical dialectology. Her research on Middle English dialectology has principally focused on the geography of the lexicon on which she has produced a number of publications and presented 
conference papers. These have dealt with both the practical results of the research and the methodological issues underpinning it.

mlinares@dfing.uhu.es

Joyce's Heirs: Joyce's Imprint on Recent Global Literatures.

Edited by Olga Fernández Vicente; co-editors, Mari Mar Boillos Pereira, Richard Jorge Fernández and Paulo Cortázar Billelabeitia.

Bilbao: Servicio de Publicaciones de la Universidad del País Vasco, 2019.167 pp.

ISBN: 9788498607277

\section{Reviewer: Margarita Estévez-Saá (University of Santiago de Compostela)}

James Joyce's literary work and figure continues to exert influence upon writers, academics and readers all over the world, and Spain is not an exception. Joyce's Heirs is a recent instance of the continuing interest of Spanish scholars and writers in the Irish genius, as it is also the case of the special edition of the Revista de Literatura etc that has also dedicated its 21 issue, coordinated by Juan Gavilán, to Joyce (2019). The collection of essays edited by Olga Fernández Vicente includes the contributions of well-known specialists on Joyce and on Irish literature, as well as the research of young scholars who guarantee the future of Irish and Joycean studies in Spain.

Supported by the Research Group LAIDA (Literatura eta Identitatea Ikerke ta Taldea), coordinated by prestigious literary critic and writer Jon Kortazar Uriarte, the volume begins with the chapter “'Joyce Is My Man': Kate O'Brien and James Joyce” by Ainizane Legarreta Mentxaka, an expert on Kate O'Brien, who offers a most interesting and well-documented discussion and comparison between Joyce's topics and aesthetics and Kate O'Brien's, in relation to issues such as nationhood, politics and religion. After establishing what she calls common ground, Legarreta Mentxaka proceeds to detect intertexual links between O'Brien's The Land of Spices and A Portrait of the Artist as a Young Man, and Mary Lavelle and Ulysses, focusing respectively on the protagonists' education in the first case, and on the topic of flânerie in the second. Particularly interesting is the author's attention to O'Brien's modernist style as well as her vindication of the formal interest of the Irish writer's work which contrasts with the more abundant studies that tend to focus on O'Brien's thematic concerns in detriment of aesthetics.

Legarreta Mentxaka's chapter is followed by Olga Fernández Vicente's reflection on how Joyce surpassed modernist aesthetics and interests, so that, perhaps, placing Fernández Vicente's piece beforehand could have more opportunely framed the comparative study between Joyce and O'Brien. It should be added that any study of Joyce's modernist aesthetics, and this applies to the two contributions, must necessarily take into consideration the still unsurpassed contribution by Weldon Thornton, The Antimodernism of Joyce's "A Portrait of the Artist as a Young Man" (1994).

The next three chapters of Joyce's Heirs try to establish connections between the Irish genius and predecessors from Irish literature such as Bram Stoker and Charles Maturin, and, more surprisingly, relate Joyce with popular works such as the Harry Potter Series.

Therefore, Richard Jorge proposes in "'Baleful distractions': the female body in James Joyce's 'The Dead' and Bram Stoker's 'The Coming Home of Abel Behenna'" a quite unexpected comparative analysis of the uses of female figures in Irish literature in relation to 
colonial and postcolonial contexts and images that he illustrates with a tale by Bram Stoker and with Joyce's most accomplished short story. Jorge's attempt is certainly a difficult one since he is comparing a one-dimensional even secondary character, Sarah Trefusis, from Stoker's "The Coming Home of Abel Behanna" with the more complex, multidimensional and controversial portraits of the Misses Morkan, Miss Ivors, and Gretta Conroy, forgetting the author the also meaningful presence of Lily at the beginning of Joyce's "The Dead".

In a similar line, Charlie Jorge delves on Northrop Frye's theories on literary archetypes and, in particular, on the Great Mother or Great Goddess Archetype as formulated by Eric Neumann, as a critical context for his analysis of the mother figure in Joyce's "The Boarding House" and in the "Tale of the Indians" included in Charles Robert Maturin's novel Melmoth the Wanderer. As the title of the contribution announces ("The Terrible Mother Archetype in James Joyce's 'The Boarding House' and Charles Maturin's Melmoth the Wanderer"), he is going to highlight the negative attributes of the previously mentioned archetype that he allegedly identifies in the portraits of both Mrs Mooney and Donna Clara. Despite the author's efforts, sometimes it seems that the characters do not easily fit in the archetype, most particularly in the case of Joyce's much critically debated characterisation of his female protagonist.

It is always tempting to study topics such as the representation and function of female figures in Joyce's work, or topics such as the Irish writer's treatment of motherhood or fatherhood in comparison with other authors, and Nerea Unda's piece " The father without a son be not a father, can the son who has not a father be a son?': The Quest for Paternity in Ulysses and Harry Potter" is a further instance of this kind of studies in Joyce's Heirs. Notwithstanding, critics opting for such analyses must always try to, first, take into account the literature previously written on the topic (which in Joyce's case is over abundant) and, second, to make sure that there is real ground for the establishment of confluences. Joycean critics have carried out a Herculean effort to revise initial simplifications and even misconceptions detected in early studies of the Irish writer's works, and this has been particularly the case with feminist and gender analyses which have fortunately proliferated since the late 1980s, and whose main objective has been precisely to deploy the complex, multidimensional and antiessentialist nature of Joyce's portraits of male and female characters. This is precisely one of the most challenging aspects when studying Joyce's processes of characterisation, since the Irish genius managed to represent male and female figures that usually defy any attempt at encapsulation, even at an early stage in his literary career.

The two contributions centered on Finnegans Wake included in the volume are of undeniable interest for Joycean studies and provide further knowledge on Joyce's process of composition of his book. Ricardo Navarrete Franco, the most salient especialist in Spain in the last work of the Irish author, offers a carefully detailed piece of genetic criticism in his chapter "The Book of the Dead in Finnegans Wake: An Approach Through Joyce's Late Additions". Navarrete Franco demonstrates how focusing on the later additions from The Book of the Dead that Joyce incorporated in 1936 and 1937 helps us to understand the extent to which The Book of the Dead is present in Finnegans Wake. Navarrete convincingly reaches the conclusion that, in contrast with Christian beliefs that emphasise the spirit in the afterlife, Joyce understands resurrection as resurrection of the body and illustrates how his careful study of those passages that the Irish writer borrowed from the Egyptian ritual allows him to conclude that Joyce associated ressurection with Earwicker, and with a process that involves "listening to a voice, receiving a Kiss, beating of the heart, looking up, opening the mouth, breathing, speaking, walking and the restoration of the penis", that is, "to stay with the body, to be able to eat, and drink, and dance, and jump" (102). 
Similarly well-documented and skilfully argued is Macarena Martín Martínez's vindication of Joyce's use of the Catholic Mass in the fable of "The Ondt and the Gracehoper". After revising previous interpretations of the fable, Martín proceeds to identify multiple Christian motifs and values and even demonstrates how the most important rites of the Catholic Mass can be identified throughout the fable, such as the Penitential Rite, the Gloria, the Deo Gratias, the proclamation of the Gospel, the Homily, the Rite of Peace, the Profession of Faith, the Liturgy of the Eucharist, the Consecration, the Lord's Prayer, the Holy Communion and the Concluding Rites. Macarena Martín does not fail to detect changes in content as well as in order which nevertheless are not as radical and complete as to consider that Joyce was invoking a Black Mass. Furthermore, the rigour of Martín's genetic study leads her to conclude that, since Joyce added the references to the Mass after the composition of the fable, these allusions, rather than serving as a structural element, were used by the Irish author as further formal and thematic overall support to the fable.

The two genetic studies of Joyce's Finnegans Wake are followed by Guillermina Heredia Campos's contribution that, after trying to distinguish conceptually between superstitions and beliefs, proceeds to identify them in Joyce's Ulysses in "Learning about Superstitions and Irish Beliefs Through Ulysses", and thus she refers to the particular meaning that, following Don Gifford, Joyce associated with certain colours, numbers, days, objects, charms and amulets, etc.

Joyce's Heirs also includes a most interesting interview with Xabier Olarra, the translator of Ulysses into Basque (2015). Olarra, led by the interviewer Olga Fernández, reflects on the difficulties of the translation, especially taking into account the peculiarities of the pre-Indo-European Basque language, and comments on how he managed to deal with many of the stylistic challenges of Joyce's masterpiece.

As can be deduced from the previous lines, and it is usually the case in this type of collections, some chapters contribute more than others to the advancement of knowledge in Joycean studies, having some of the analyses a more divulgative nature, which should not necessarily be discarded, since each of them appeals to different readers with diverse interests.

Since the volume already contains an introduction in which the contributions included are explained, one finds it unnecessary the inclusion of abstracts preceding each chapter, as well as the key words. Overall, the editing of the essays can be certainly improved, especially if it is to appear in paper format in the future. Furthermore, its present condition in electronic form allows for an easy mending of some limitations such as the absence of information on contributors, or some inconsistencies in style. Finally, given the fact that the Basque language is a minority language, it would be equally interesting to include in the future a bilingual version of the last contribution by Joxe Mari Iturralde which, despite being entitled "Joyceday" appears only in Basque, something that prevents most of us from grasping the impact of Joyce's figure on the great Basque creator.

Margarita Estévez-Saá is Senior Lecturer in English and American Literature at the University of Santiago de Compostela. She has published articles and book chapters on James Joyce, modernist and post-colonial literature, contemporary Irish literature, critical theory, feminist criticism, and on ecofeminist and animal studies.

margarita.estevez.saa@usc.es 
Samuel Beckett en español. Bibliografía crítica de las traducciones de su obra.

Nuria Fernández-Quesada, José Francisco Fernández Sánchez, Bernardo Santano Moreno. Almería: Editorial Universidad de Almería. Colección: Humanidades 68. Serie: Literatura 2, 2019. $234 \mathrm{pp}$.

ISBN: 978-84-17261-68-9.

Reviewer: María José Carrera (University of Valladolid, Spain)

Beckett scholars in Spain and Latin America can only welcome the publication of Samuel Beckett en español. Bibliografía crítica de las traducciones de su obra (2019), a reference work that comes to ameliorate the endemic scarcity of academic publications on the Irish author in Spain and/or in Spanish. Like other good data banks, this one proves an invaluable source for future researches by providing a carefully laid-out path for others to walk on: any future research on how and when Samuel Beckett has been rendered into the Spanish language - and into Catalan, Galician, and Basque - will have to start from this recent publication.

The book is an annotated catalogue of the translations of Beckett's works published both in Spain and Latin America over a period of sixty-one years (1954 to 2015), preceded by a prologue signed collectively by the three authors (9-12) and an introductory essay authored by Nuria Fernández-Quesada: 'España, 'A Beckett Country?' Seis décadas de traducción y olvido" (13-38). From the reading of the latter we get the picture of how different the reception of Beckett's texts in Spain and in other European countries was: if Beckett was extolled in 1950s France, England, and Germany as one of the great challengers of realism in fiction and drama, in Spain his works were found to be completely alien to the bourgeois morality promoted by the dictatorship of Franco. The Regime's official censors, as well as the journalistic critics, had a field day with Beckett, as testified by the existence of fifty-four theatrical censorship files, mostly for amateur productions, with only one leading to the actual prohibition of a commercial performance in 1959. Beckett's texts were subjected to heavy suppressions and corrections, and these interventions, Fernández-Quesada claims, were tantamount to a prohibition for the theatre companies (23).

Two landmarks in the publication of the translations of Beckett's texts in Spain can be singled out from Fernández-Quesada's account: the 1960 Catalan translation of Waiting for Godot - the first extant version of a Beckett text in Spain - and the 1989 critical bilingual edition (English-Spanish) of Happy Days by Antonia Rodríguez-Gago. A decade of renewed interest in Becket's work follows the year of the author's death and, hence, a larger number of translations materialise. With a number of previously untranslated texts now seeing the light in Spanish, the twenty-first century somehow alleviates the bleak panorama of having some of the main texts in Beckett's drama and prose still only available in the translations of the censorship period.

As well as bearing witness to these chronological ups and downs in the translators' involvement with Beckett's works, the information which the authors of Samuel Beckett en español have carefully laid out for its readers also evidences a lack of acknowledgement of the bilingual nature of many of Beckett's texts. Indeed, Beckett's bilingual canon has always been a source of controversy when it comes to turning his works into other languages: from which language is the text (to be) translated? Which language is favored by the different translators in the different target languages? By looking into the catalogue of translations in this book, scholars can now confirm that the Spanish versions of Beckett's texts tend to favor the language in which they were first written by the author, with notable exceptions like the 1963 translation of Días felices from the French Oh, les beaux jours (1963) preceding the 
1989 translation from the English Happy Days (1961). This is in line with an overall preference among Spanish translators for French over English as a source language.

The three hundred and sixteen bibliographical cards which compose the catalogue have been organised by the authors into six sections titled: Anthologies and Compilations (referring, respectively, to selected writings in the same literary form and miscellanea of texts from the different genres practiced by Beckett), Narrative, Drama, Poetry, Essays, and Other genres (a miscellany of radio and TV plays, the screenplay for Film, individual texts from Disjecta like "German letter of 1937", "Pour Avigdor Arikha", "Hommage à Jack B. Yeats", etc.) A hundred and thirty entries make Poetry the longest section, which is understandable given that each individual poem's translation is singled out and provided with its own bibliographic card, most of them cross-referencing to five of the poetic anthologies and miscellaneous compilations included in the first section. The numbers of the card entries for the prose works (fifty-seven) and for the plays (fifty-three) are interesting in themselves as an indication of the different fates of Beckett's main texts in Spanish: one would expect his major dramatic works to have received a closer attention on the part of the translators but, as the catalogue shows, there have been few attempts, if any, to tackle the rendition of those works in Spanish after the versions of the 1960s and 1970s, while Galician, Basque, and Catalan translations were produced. At the same time, a number of Beckett's prose texts have late-twentieth and twenty-first translations: Worstward Ho (2001), Molloy (2006, Galician), "From an Abandoned Work" (2008), Mercier and Camier (2013), Texts for Nothing (2015), etc.

With the exception of the Anthologies and Compilations, which are given to the reader with the Spanish title with which they were published, each catalogue card provides the reader with the title of the work in the original language (or languages when the work is bilingual); the title of the translated work (in Spanish, Catalan, Galician, or Basque); the language (languages, in the case of the Anthologies) from which the text has been translated; the name of the translator(s); the place of publication and the publishing hose; the name of the journal (if applicable); the year(s) of publication; the ISBN; and either the page numbers or the number of pages of the publication. To ease the path of the reader through the catalogue, the original titles of the works (or, again, of the translations in the case of the Anthologies and compilations) are organized alphabetically, each title acting as a heading for a new subdivision within each of the six main sections of the catalogue.

A descriptive section accompanies the bibliographic cards providing mostly factual information such as the list of contents compiled in each of the anthologies and miscellanies or cross-referencing to other cards in the catalogue (most of them sending the reader to those in the Anthologies and Compilations section). The prologues, essays, introductions, biographical sketches, and translators' notes that may accompany each publication are also listed and, most of them, summarized. The collective overview of these paratexts that Samuel Beckett en español facilitates makes the reader aware of at least two facts: most try to pinpoint Beckett's works as belonging to some trend or another; and a vast majority presents Beckett as the author that brings despair to the quotidian, emphasizing the existentialist reading of his works, and largely ignoring their humor and linguistic brilliance. Indeed, well into the twentyfirst century we continue to be introduced to Beckett as an absurdist author in the Galician (2005) and Spanish (2014, Mexico) translations of Waiting for Godot.

However, there are notable exceptions. In her 1989 translation of Happy Days Rodríguez-Gago feels the need to claim for an interest in Beckett's language and not so much on his personal life and oeuvre. And Jenaro Talens, another of the big names in the Beckett world in Spanish, also discusses the problems posed by Beckett's use of language. When he "apologizes" for the liberties he has taken in translating Beckett's poetry on account of the difficulty of replicating the "violence exerted on the French language" in the original texts 
(189), one cannot help but recall the amount of abuse that Beckett threw on his own selftranslations and those of others translating him. Beckett actually approached the translations of his works by others in much the same way in which he approached his own translation tasks: he loathed the process and the results intensely but then begged for the respect due to the pains taken by the translator. The pioneer translation of En attendant Godot by Trino Martínez Trives (1954) is a good case in point. Beckett claims repeatedly that "the Spanish translation is execrable", "bad", "full of mistakes \& omissions and unjustifiable liberties", and "awful" (Beckett 447, 448, 449, 456) only to refuse, exactly one year later, to forbid Martínez Trives to put on his play with the censors' cuts 'in view of the trouble he has taken and the difficulties he has had to overcome" (Beckett 529).

Talens's reflections on the "linguistic liberties" he took led me to recall Beckett's disdain for Martínez Trives's "unjustifiable liberties", which in turn resulted in seeing him take sides with the translator who cannot escape the censors' axe in 1950s Spain. May this serve as an example of the sort of connection that scholars can establish between the content made available by Samuel Beckett en español and the rest of Beckett's scholarly sources. Many other incursions are bound to be made into the little-trodden world of the translation and reception of Samuel Beckett's texts thanks to this valuable reference work and its aim to provide a "form to accommodate the mess" of the translations of his works in Spain and Latin America.

\section{Works Cited}

Beckett, Samuel. The Letters of Samuel Beckett. Volume II: 1941-1956. Ed. George Craig, Martha Dow Fehsenfeld, Dan Gunn and Lois More Overbeck. Cambridge: Cambridge University Press, 2011.

María José Carrera is Lecturer in English at the University of Valladolid, Spain. She has published mainly on Samuel Beckett's annotations for his translations of An Anthology of Mexican Poetry (1958). She is also the author of book chapters on Samuel Beckett's short prose, and is currently preparing a monograph on Beckett's involvement with the literature in Spanish.

mcarrera@fyl.uva.es

Hannah Lynch and Spain: Collected Journalism of an Irish New Woman, 1892-1903.

Pere Gifra-Adroher and Jacqueline Hurtley

Venezia: Edizioni Ca' Foscari, 2018. 250 pp.

ISBN: 978-88-6969-293-2

Reviewer: Verónica Membrive Pérez (Universidad de Almería)

After publishing the biography of Walter Starkie in 2014, in which Jacqueline Hurtley showed her interest and insight on Irish writers who lived in and wrote about Spain, she has now turned her attention to the Irish writer and journalist Hannah Lynch (1859-1904). In collaboration with Pere Gifra-Adroher, this book complements Binckes and Laing's biographical account of Hannah Lynch 1859-1904: Irish Writer, Cosmopolitan, New Woman, recently published. Both books coincide in the inclusion of the term "New Woman" in the 
title, as it would mark Lynch's entire literary and journalistic career. As it happened with the Match Girls and the Ladies' Land League, the Irish New Woman turned out to be a cultural sensation at the end of the $19^{\text {th }}$ century since this group experimented with the female character in their literary production and "the specific context of this foundational group of New Woman writers at that particular point in Irish history facilitated their breach with the dominant culture, giving them the impetus and the tools to construct alternate social realities in their fiction" (O'Toole 2013: 2).

By the time Hannan Lynch sojourned in the country, Spain's economy was mostly based on agriculture and the colonial disaster of 1898 and the rise of the Catalan independent movement elicited a reversal of Spanish self-identity as a global power to the emergence of a decadent self-perception. The already well-established links between Ireland and Spain were not exclusively military, trading or religious, and the extensive Irish commercial activity in Spain played "an important role in the industrialization of Andalusia in the $19^{\text {th }}$ century" (García-Álvarez de la Villa and Terry 2016: 79). By this time, the interest in Spain was not exclusive of British Romantic travellers in the $19^{\text {th }}$ century. In fact, we find Irish travellers such as the historian Martin Haverty, ${ }^{1}$ who visited Spain for three months in 1843 and published Wanderings in Spain in 1843 (1844). The research on Haverty's trip to Spain revealed that he found some similarities between Spain and his native country, for example when he described flamenco and considered that he could compare it with "the Keena, or 'funeral cry', as it is heard in the West of Ireland" (Haverty 1844: 146); or the posadas, "somewhat in the same style as we find in mud-built houses in Ireland" (143). Another example would be Michael Joseph Quin, ${ }^{2}$ another journalist who visited the Iberian Peninsula in 1822. He reported his experiences in Spain in 1822 and 1823 for the Morning Herald, which were published in book-form as A Visit to Spain later in 1823. Although he was not "immune to the ever present stereotypes which fill travel literature on Spain throughout the ages" (López-Burgos del Barrio 2005: 342), he became surprised by the similarities between his native country and Spain, specifically in Vitoria (Basque Country). Unlike British travellers of the $18^{\text {th }}$ century and the beginning of the $19^{\text {th }}$ century, these two Irish authors did not consider their journey as that of a professional traveller nor did they look for the picturesque or the sublime in the country. Their aim was to inform about the social and political changes happening in Spain after the first Carlist War (Krauel Heredia 2005: 323). These two examples would suggests that the Irish travelling and journalistic experience to Spain in the $19^{\text {th }}$ century was exclusively male. However, Gifra-Adroher and Hurtley's book on Lynch defies that conviction and places great value on this Irish female writer's contribution to the cultural links between Ireland and Spain. Lynch's journalistic pieces show that she travelled around many Spanish cities and stayed in Barcelona visiting her sister Nannie who worked as a governess, something that other Irish female authors such as Kate O'Brien or Maura Laverty would do in the 1920s in the Basque Country.

The book is divided into two main parts. The introductory section does not only include a summary of Lynch's personal and professional life and a description of Irish and Spanish society of late $19^{\text {th }}$ century, but also an accurate a very well researched critical approach to Lynch's personal and literary Spanish experience. The second part collects Lynch's nineteen articles on Spain in a chronological order from 1892 to 1903. The significance of this book stems from its special attention to Lynch's literary image of Spain in her fiction and collected journalism to demonstrate that the Irish gaze has its own features separated from the traditional romanticised representation of Spain conveyed by British travellers and visitors for centuries. Even if the book acknowledges Lynch's romanticized representation of the country in some occasions, it remarks how the author also tended to search for unexplored cities and give her critical views on Spanish politics and religious issues. Nevertheless, Lynch's journalistic accounts on the country go beyond a social critique 
or commentary on the backwardness of the country, since parallelisms between her native country and Spain arise many times: "Ireland remained a presence or point of reference in Lynch's work. It is woven into her Spanish articles, from first to last, as well as into her fiction" (Gifra-Adroher and Hurtley 2019: 27). Besides, the second standpoint to be underscored in this book is the content devoted to articulate Lynch's emphasis on Spanish women and their roles in Spanish private and public life since which "repeatedly surfaces" her writing (Gifra-Adroher and Hurtley 2019: 44). She was familiar with $19^{\text {th }}$ century male gaze on Spain and decided to put the spotlight on the unbalanced female experience in the country, and two articles on violence towards Galician women and her indignation are worth noting.

Of particular interest is the subsection titled "Spain and the Irish Gaze". According to the authors, Irish travellers to Spain became "curiosos impertinentes" (2019: 33), as these imagined the country according to previous Romantic travellers. However, by reviewing an acknowledging the increasing presence of Irish writers (mostly male) in the country during this century and afterwards, this section stands for the relevance of Hiberno-Spanish relations through centuries and the establishment of a distinctive literary gaze on the country. The subsection that addresses Lynch's novel set on Spain Jinny Blake (1897) is noteworthy too as the central character is a strong woman who resembles those characters found in Kate O'Brien's Mary Lavelle and Maura Laverty's No More than Human since all of them struggle to overcome "boundaries of class, gender and space" (Gifra-Adroher and Hurtley 2019: 66) in a place considerably more backward than other European countries, particularly for women. Finally, the closing subsection reviews Lynch's travel book around Toledo, titled Toledo: the Story of an Old Spanish Capital (1898) with a special focus on its artistic value. To sum up, this critical edition and collection of Hanna Lynch's writings on Spain is a thorough and illuminating study that highlights not only the figure of this Irish female writer and her unique gaze on the country but also the importance of further examining literary Hiberno-Spanish links, specially from neglected or overlooked female writers that would convey their Spanish experience in fictional works or travelogues, for whom it could be claimed that Lynch would act as a precursor.

\section{Notes}

\footnotetext{
${ }^{1}$ Martin Haverty (1809-1887) was an Irish historian and journalist who reported his extensive journey around Europe (1851) in his newspaper articles.

${ }^{2}$ Michael Joseph Quin (1796-1843) was an Irish journalist and editor who founded the Dublin Review, a Catholic periodical. He also travelled extensively around Europe.
}

\section{Works Cited}

Binckes, Faith and Laing, Kathryn. Hannah Lynch 1859-1904: Irish Writer, Cosmopolitan, New Woman. Cork: Cork University Press, 2019.

García-Álvarez de la Villa, Beatriz and Terry, Kevin. "Terrys in Spain and Latin-America: Exile and Rise of an Irish Merchant Family." Estudios Irlandeses 11 (2016): 69-81.

Haverty, Martin. Wanderings in Spain in 1843. London: T. C. Newby, 1844.

López-Burgos del Barrio, María Antonia. "Michael Joseph Quin, Irish Journalist in Spain in 1822." Humour and Tragedy in Ireland. Ed. Patricia Trainor de la Cruz and Blanca Krauel Heredia. Málaga: Universidad de Málaga. Servicio de Publicaciones, 2005. $335-42$.

Krauel Heredia, Blanca. "Martin Haverty: un irlandés en la España de Isabel II." Humour and Tragedy in Ireland. Ed. Patricia Trainor de la Cruz and Blanca Krauel Heredia. Málaga: Universidad de Málaga. Servicio de Publicaciones, 2005. 323-34. 
O'Toole, Tina. "Introduction: the Irish New Woman". The Irish New Woman. Palgrave Studies in Nineteenth-Century Writing and Culture. London: Palgrave Macmillan, 2013. 1-16.

Verónica Membrive studied English and earned a Master's Degree in English Studies in 2011. She completed her Ph.D. at the University of Almería (2017) on Irish travel writers in Spain during the twentieth-century. She has delivered papers on Walter Starkie, Kate O'Brien and Pearse Hutchison and their travels in Spain. She is currently teaching English at the University of Almería. Her field of research is Irish Literature, with a special focus on the relationships between Ireland and Spain. She has been awarded the International George Campbell Award for her research on Hiberno-Spanish cultural relations (University of Málaga, 2018).

v.membrive@ual.es

¡Salud! Un irlandés en la Guerra Civil española. Peadar O’Donnell.

Edición de Alberto Lázaro

Salamanca: Amarú Ediciones, 2019. 242 pp.

ISBN 978-84-8196-388-5

\section{Reviewer: Marisol Morales-Ladrón (University of Alcalá)}

La recuperación de la memoria histórica y cultural se ha convertido en un tema clave de la actualidad política, con defensores y detractores contribuyendo a un debate sin fin sobre la función del pasado y del recuerdo en la construcción de "la verdad". Como seres históricos que somos, inevitablemente nuestra identidad es indisoluble de nuestra memoria, tanto individual como colectiva, conocida o heredada, cuyas huellas dejan marcas indelebles que el tiempo suele encargarse de borrar. Los anales, los documentos o los recuerdos son los únicos antídotos contra los silencios y los olvidos de la historia, no siempre contada con imparcialidad o distancia, y frecuentemente simplificada. Además, los grandes acontecimientos históricos, como las guerras, suelen estar sometidos a incesantes revisiones e interpretaciones desde las más variadas perspectivas. Tal es el caso de la Guerra Civil española, uno de los sucesos históricos que más interés internacional generó y que sigue ocupando un gran espacio en la recuperación de esta memoria colectiva de la que todos somos parte.

Uno de los países que mayor seguimiento hizo del desarrollo del conflicto bélico español fuera Irlanda. Esto es algo que no sorprende, teniendo en cuenta que allí se había librado una década antes su propia Guerra Civil entre los opositores y defensores del tratado que acabó dividiendo la isla en dos - conocidos como los "pro-" y los "anti-Treaty"-, y que negociaron Michael Collins y Arthur Griffith en Westmister en diciembre de 1921, con la firme convicción de que era la única alternativa posible a una larga historia de opresión británica. Pero el caso irlandés, como explica Alberto Lázaro, responsable del volumen que es objeto de esta reseña, fue complejo y paradójico, dado que prestó apoyo a los dos bandos: el republicano, seguido principalmente por la Columna Connolly; y el nacional, con la Irish Brigade que dirigió el General Eoin O'Duffy (11). Aunque de forma casi accidental, es el periodista y escritor irlandés Peadar O’Donnell, quien, en un viaje a España en julio de 1936, 
es testigo del alzamiento militar y comienza a documentar las circunstancias que rodearon la realidad sociopolítica del momento, siempre con la mirada puesta en su propio país y en sus reivindicaciones nacionalistas.

¡Salud! Un irlandés en la Guerra Civil española, editada por Alberto Lázaro, supone el primer acercamiento al público español del papel que jugó este irlandés en nuestra Guerra Civil. Se trata de una traducción anotada y comentada del texto original inglés, iSalud! An Irishman in Spain (1937), publicado por Methuen en 1937, en el que O'Donnell trató de aportar una visión más o menos imparcial de los acontecimientos que se fueron sucediendo en esos primeros meses. De ahí, la pequeña licencia en el giro de la traducción del título que, según Lázaro, se debe a la necesaria referencia a la Guerra Civil, tan relevante para la comprensión del texto (47). El estudio de la recepción de la Guerra Civil española en Europa, así como el análisis de una gran cantidad de archivos de censura de autores anglófonos en España es una línea de investigación desarrollada amplia y exitosamente por el catedrático de Literatura inglesa de la Universidad de Alcalá, Alberto Lázaro. Muestra de ello es la publicación en la misma colección salmantina Armas y Letras (Amarú ediciones), del volumen titulado Corresponsal en España: crónica de la Guerra Civil (2012), sobre el papel que desempeñó el periodista inglés Frank Pitcairn (Claud Cockburn) en la difusión de las noticias de la guerra en la prensa internacional y sobre su propia experiencia como soldado voluntario. A este monográfico, se añade un buen número de publicaciones sobre el papel de la censura, a menudo paradójica e inconsistente, en la recepción de escritores británicos e irlandeses en España, como H. G. Wells, George Orwell, John Gower, Oscar Wilde, James Joyce, Doris Lessing o Thomas Hardy, entre otros.

¡Salud! Un irlandés en la Guerra Civil Española consta de dos secciones claramente diferenciadas: una primera, que contiene una larga y detallada presentación de la vida y obra de Peadar O'Donnell, así como un análisis contextual del período tanto en Irlanda como en España; y una segunda, que incluye la traducción anotada del texto original. Centrado en los tres meses que pasó O’Donnell en España, tras asentarse en Sitges en Julio de 1936, este documento recoge su creciente interés por la situación política española, y sus andanzas y tribulaciones. Fue testigo y partícipe de la formación de las Brigadas internacionales y de la llegada de los voluntarios extranjeros a nuestro país. No obstante, uno de los aspectos más valiosos de este documento, apunta Lázaro, es su carácter personal, al haber presenciado en primera persona los inicios del alzamiento y haber recogido las reuniones mantenidas con sindicalistas y con personajes del ámbito político y religioso, así como haber aportado testimonios y retratos de las vidas comunes de las gentes.

El monográfico comienza con una detallada cronología, que recoge día a día el tiempo que O’Donnell pasó en España, desde poco antes del estallido de la Guerra Civil, en julio de 1936, hasta septiembre de ese mismo año. En el apartado dedicado al "Autor y su tiempo", Lázaro le sitúa como una figura relevante del creciente nacionalismo irlandés y como escritor y periodista. Fue un ferviente defensor de las clases oprimidas, especialmente de los campesinos que vivían en enclaves rurales ahogados por los impuestos que les exigían los grandes terratenientes Anglo-irlandeses, además de sindicalista y activista comprometido con la causa irlandesa hasta su muerte. Llegó incluso a afiliarse al IRA en 1919, tras la derrota del Levantamiento de Pascua de 1916, y a participar en reyertas en pro de la independencia de Irlanda. La firma del Tratado Anglo-Irlandés - que dividiría a Irlanda en 26 contados agrupados bajo la denominación de Éire y de otros 9, que conformarían Irlanda del Norte reactivó su nacionalismo mostrándose contrario a la decisión y participando en la cruenta Guerra Civil irlandesa que dividió a familias, oponiendo a padres contra hijos y hermanos. Estuvo arrestado en varias ocasiones, durante las cuales se dedicó a escribir ensayos satíricos y otros textos de ficción. Algunos de estos documentos son clave para comprender la realidad 
política del momento. También luchó contra el incipiente fascismo que empezaba a asolar Europa desde una clara ideología política de izquierdas. A principios de 1936, precisamente con la intención de buscar un retiro para escribir un libro sobre las reformas agrarias, se dirigió a España y se instaló en Sitges. Presenciar las primeras fases del alzamiento y la resistencia de la clase obrera le llevó a involucrarse en la batalla. Aunque se marchó a su país, volvió semanas después y visitó varias ciudades, incluida Madrid, para tener una mejor visión de lo que estaba sucediendo, llegando a entrevistarse con personalidades relevantes del panorama político español. A su vuelta definitiva a Irlanda, siguió manteniendo el interés por la evolución de los acontecimientos en España, apoyó al bando republicano reclutando soldados irlandeses y colaboró con las Brigadas Internacionales, además de proporcionar ayuda humanitaria.

El segundo apartado, dedicado a la "Proyección social de la obra de O’Donnell", se centra en su faceta como escritor. Con un gran legado literario, escribió siete novelas: Storm (1925), Islanders (1927), Adrigoole (1929), The Knife (1930), On the Edge of the Stream (1934), The Big Windows (1955) y Proud Island (1975). Produjo cuatro autobiografías, una obra de teatro, varios cuentos y una gran cantidad de artículos periodísticos, junto a panfletos, manifiestos y ensayos. Además, dirigió las revistas An Phoblacht (La República), un semanario vinculado al Sinn Féin, el brazo político del IRA, y posteriormente, The Bell, con un tinte más cultural y reivindicativo de la libertad de expresión. La importancia de su obra se encuentra esencialmente, según explica el responsable de la presente edición, en que al ser marcadamente biográfica y al estar muchas de las historias basadas en hechos reales, permite vislumbrar la realidad de la Irlanda del momento. O’Donnell se perfila, así, como un incansable defensor del débil, del oprimido o del pobre, ante la patente desigualdad y precariedad de las zonas rurales y los abusos que ejercían las clases más favorecidas. Como destaca Lázaro, su pluma era "un arma" desde la que poder combatir las injusticias sociales y la privacidad de libertad que imperaba en la época (27).

Un tercer apartado se centra en el análisis del texto mismo de O'Donnell, en cuanto a su origen, estilo narrativo y contenido. Es interesante la aclaración que se hace sobre el significado del término "Salud", que encabeza el título, y que el lector actual asociaría con su uso más común como expresión para brindar. En este caso, el editor explica que se emplea para evocar la forma en que se saludaban los republicanos frente a los tratamientos más protocolarios y, en cierto modo, serviles que utilizaban los nacionales. Como explica Lázaro: "Desde un primer momento, el autor se da cuenta de que esta expresión era algo más que un saludo; era un término identitario de la clase trabajadora que se oponía a la sublevación militar" (35), y añade que también el escritor británico George Orwell se había hecho eco de esta forma de expresión, que veía como algo inseparable de la ideología de clase. Los objetivos de O’Donnell con esta obra eran difundir la ideología republicana en una Irlanda dividida tras su propia Guerra Civil y denunciar la supremacía del conservadurismo católico. De este modo, "quería contrarrestar toda la propaganda antirrepublicana que dominaba la opinión pública irlandesa desde que estalló la guerra", dado que el apoyo a Franco frente a los rojos ateos que atacaban iglesias y clérigos era cada vez más patente (36).

Aunque su vínculo con España, como él mismo reconoce, surge de su corta visita al país, su interés por comprender la política y sociedad españolas es incuestionable, tratando de evitar caer en prejuicios y simplificaciones culturales, que tanto caracterizaban a los escritos de la época por parte de otros autores foráneos. Para Lázaro, su crónica se sitúa en un género híbrido que fusiona historia con periodismo y literatura, por lo que se concede ciertas licencias (44). A veces se abunda en referencias a lugares concretos que visitó y donde contactó con personas de ámbitos distintos, ofreciendo gran cantidad de detalles, y en otras no hay suficiente información para poder localizar la escena. Como no es una crónica en su 
sentido más estricto, el rigor de los detalles no es un elemento sustancial. Sí es relevante que la narración se haga en primera persona y que se recojan vivencias, reflexiones y comentarios, dejando claro que no se trata de un documento histórico, aunque se insiste en "su gran valor documental" (46), sin caer en la propaganda o en la simplificación de los acontecimientos.

A la luz de la larga e ilustrativa introducción, cronología, explicaciones y anotaciones textuales aportadas, se evidencia que esta publicación viene a llenar un vacío existente con respecto a la recepción que la Guerra Civil española tuvo en escritores anglófonos, concretamente en este caso, en la obra del irlandés Peadar O'Donnel, y demuestra que este es un campo de investigación fértil y lleno de posibilidades. Aunque existen varias biografías de la obra de este autor, ¡Salud! ha sido una obra prácticamente ignorada por la crítica. Esta edición comentada y anotada por Lázaro es la primera traducción al castellano que existe. Como se adelantaba al comienzo de esta reseña, la recuperación de la memoria histórica, como compromiso ético con la búsqueda de la verdad, requiere desenterrar vidas de personajes que jugaron un papel clave en la difusión de nuestra cultura, haciendo de antídoto contra los olvidos voluntarios o involuntarios de la historia. Es por ello, que este monográfico contribuirá a difundir esta línea de investigación abierta desde hace unas décadas, permitiendo que el lector español pueda acceder a una fuente documental tan personalista y a la vez tan ilustrativa de la realidad del momento.

Marisol Morales-Ladrón is Professor of English and Irish Literature at the University of Alcalá where she has been teaching since 1994. Trained in the fields of English Philology, Hispanic Philology and Psychology, her research focuses on gender issues and literature written by women. Her publications include Breve introducción a la literatura comparada (1999) and Las poéticas de James Joyce y Luis Martín-Santos (2005). She has edited the monographs Postcolonial and Gender Perspectives in Irish Studies (2007) and Family and Dysfunction in Contemporary Irish Narrative and Film (2016), and has co-edited Glocal Ireland: Current Perspectives on Literature and the Visual Arts (2011), as well as two studies on feminist criticism. She is currently Vice President for Quality Management at the University of Alcalá, and Vice Chairperson-Europe of the International Association of Irish Studies (IASIL).

marisol.morales@uah.es 